\title{
Escherichia coli 0157:H7 SURVIVAL IN TRADITIONAL AND LOW LACTOSE YOGURT DURING FERMENTATION AND COOLING PERIODS
}

\section{SOBREVIVÊNCIA DA Escherichia coli O157:H7 EM IOGURTE NATURAL E COM BAIXO TEOR DE LACTOSE DURANTE A FERMENTAÇÃO E O RESFRIAMENTO}

\author{
Camila Sampaio Cutrim ${ }^{1^{*}}$ \\ Raphael Ferreira de Barros ${ }^{1}$ \\ Robson Maia Franco ${ }^{1}$ \\ Marco Antonio Sloboda Cortez ${ }^{1}$ \\ ${ }^{1}$ Universidade Federal Fluminense, Niterói, RJ, Brasil. \\ *Author for correspondence - camila.cutrim@yahoo.com.br
}

\begin{abstract}
The purpose of this study was to evaluate the behavior of E. coli O157:H7 during lactose hydrolysis and fermentation of traditional and low lactose yogurt. It also aimed to verify E. coli O157:H7 survival after $12 \mathrm{~h}$ of storage at $4{ }^{\circ} \mathrm{C} \pm 1{ }^{\circ} \mathrm{C}$. Two different types of yogurts were prepared, two with whole milk and two with pre-hydrolyzed whole milk; in both groups one yogurt was inoculated with E. coli O157:H7 and the other one was not inoculated. The survival of E. coli and pH of yogurt were determined during fermentation and after 12-h refrigeration. The results showed that E. coli O157:H7 was able to grow during the fermentation period (from $4.34 \log$ CFU.mL ${ }^{-1}$ to $6.13 \log$ CFU.mL ${ }^{-1}$ in traditional yogurt and $4.34 \log$ CFU.mL $L^{-1}$ to $6.16 \log$ CFU.mL $L^{-1}$ in low lactose yogurt). The samples with E. coli O157:H7 showed gas formation and syneresis. Thus, E. coli O157:H7 was able to survive and grow during fermentation of traditional and low lactose yogurts affecting the manufacture technology. Moreover, milk contamination by E. coli before LAB addition reduces the growth of $L$. bulgaricus and $S$. thermophilus especially when associated with reduction of lactose content
\end{abstract}

Keywords: $\beta$-galactosidase; EHEC; fermented milk; lactic acid bacteria; lactose hydrolysis.

\section{Resumo}

Objetivou-se no presente estudo avaliar o comportamento da E. coli O157:H7 durante o processo de hidrólise da lactose e fermentação de iogurte tradicional e com teor reduzido de lactose. Além disso, objetivou-se verificar a viabilidade da E. coli O157:H7 e a viabilidade das bactérias ácido láticas após $12 \mathrm{~h}$ de estocagem a $4{ }^{\circ} \mathrm{C} \pm 1{ }^{\circ} \mathrm{C}$. Dois diferentes tipos de iogurte com amostras controle e amostras inoculadas foram preparados, sendo dois com leite integral e dois com leite integral préhidrolisado; em ambos os grupos um foi inoculado com E. coli O157:H7 e um não foi inoculado. A 
sobrevivência da E. coli e o pH dos iogurtes foram determinados durante a fermentação e após $12 \mathrm{~h}$ de refrigeração. A partir dos resultados observou-se que a E. coli O157:H7 foi capaz de se multiplicar ou manter-se viável durante a fermentação (4,34 UFC.mL ${ }^{-1}$ para 6,13 UFC.mL ${ }^{-1}$ no iogurte tradicional e 4,34 UFC.mL $\mathrm{m}^{-1}$ para 6,16 log UFC. $\mathrm{mL}^{-1} \mathrm{em}$ iogurte com lactose reduzida). Nas amostras inoculadas com E. coli O157:H7 houve formação de gás e sinérese. Dessa forma, concluiu-se que a E. coli O157:H7 foi capaz de sobreviver e de se multiplicar durante a fermentação afetando a tecnologia de fabricação. Além disso, a contaminação do leite antes da adição das BAL reduziu o crescimento de $L$. bulgaricus e $S$. thermophilus, especialmente quando associado à redução da lactose.

Palavras-chave: $\beta$-galactosidase; bactérias ácido láticas; EHEC; hidrólise da lactose; leite fermentado.

Received on: February $1^{\text {st }}, 2016$

Accepted on: June $27^{\text {th }}$, 2017

\section{Introduction}

Escherichia coli is one of the most prolific microorganisms in human intestinal tract and it is normally harmless; however, certain strains can be pathogenic, like enterohemorrhagic E. coli (EHEC). These strains carry genetic determinants for attaching-effacing lesions that cause hemorrhagic colitis with severe abdominal pain and cramps followed by bloody diarrhea. In addition, the Shiga-like toxin production leads to additional intestinal diseases, such as hemolytic uremic syndrome and thrombotic thrombocytopenic purpura ${ }^{(1)}$. A major example of EHEC is E. coli O157:H7, which was first recognized as a human pathogen in 1982 by Riley et al. ${ }^{(2)}$ when it was associated with two outbreaks of hemorrhagic colitis. Since then, many other foodborne outbreaks have been reported involving different products such as ground beef ${ }^{(3)}$ and yogurt ${ }^{(4)}$.

Although yogurt is considered safe due to low acidity, some authors have reported E. coli O157:H7 survival during the storage period ${ }^{(5,6)}$. It has been shown that $E$ coli O157:H7 cells have an effective mechanism to resist to extreme acid stress situations, and its resistance depends on the interaction with environmental compounds ${ }^{(7)}$.

Fermented milk is widely consumed around the world and yogurt is the most popular fermented dairy product, though approximately $75 \%$ of the world's population loses the ability to digest lactose into adulthood ${ }^{(8)}$. It is known that the lactose content in yogurt is about one third lower than in milk due to fermentation conducted by lactic acid bacteria, converting lactose into lactic acid ${ }^{(9)}$. However, in some cases, the persistence of gastrointestinal malaise from the consumption of yogurt shows that the decrease of lactose content would not be sufficient to relieve the symptoms of indigestion. This led to the introduction of improvements in dairy products production, such as reduced lactose content using exogenous lactases.

The objective of this study was to evaluate the behavior of E. coli O157:H7 during lactose hydrolysis process and fermentation process of traditional and low lactose yogurt. It also aimed to 
verify E. coli O157:H7, Lactobacillus delbrueckii spp. Bulgaricus, and Streptococcus thermophilus survival after $12 \mathrm{~h}$ of storage at $4 \pm 1^{\circ} \mathrm{C}$.

\section{Materials and Methods}

The Escherichia coli O157:H7 strain (CDC EDL - 933) was obtained from the National Institute of Health Quality Control of the Oswaldo Cruz Foundation (FIOCRUZ, Rio de Janeiro, Brazil). The organisms were inoculated in brain heart infusion (BHI) broth and incubated at $37{ }^{\circ} \mathrm{C}$ for 24 hours (h). The bacterial cells were maintained on BHI and stored at $4{ }^{\circ} \mathrm{C}$. To activate the E. coli O157:H7 cells, a loop-full of BHI stored was transferred to BHI broth and incubated at $37^{\circ} \mathrm{C}$ for $24 \mathrm{~h}$.

The lactic starter culture used was an industrial yogurt culture, consisted of Streptococcus thermophilus and Lactobacillus delbrueckii spp. bulgaricus (DVS YF-L812, Christian Hansen Laboratories, Denmark). Before fermentation, culture was activated by mixing the $50 \mathrm{U}$ sachet (10 to $11 \log$ CFU.mL ${ }^{-1}$ ) to $500 \mathrm{~mL}$ of sterile $10 \%$ (w/v) reconstituted skim milk powder (Molico, Nestlé, São Paulo, Brazil) and stirred for 15 min to achieve a homogenous culture ${ }^{(10)}$. This volume was distributed into $10 \mathrm{~mL}$ test tubes, containing an approximate amount of $5 \log$ CFU.mL ${ }^{-1}$, according to Mac Farland scale, and stored at $-18{ }^{\circ} \mathrm{C}$ until yogurt production. To perform the fermentation, the culture was thawed and evaluated by the Mac Farland scale, that revealed the same initial counting, which was then added to milk samples.

Commercial (ultra high temperature) UHT whole milk was analyzed to determine $\mathrm{pH}$, titratable acidity (TA), fat content by the Association of Official Analytical Chemists (AOAC) standard Gerber method 2000.18 (AOAC, 2012), freezing point by cryoscopic method 990.22 (AOAC, 2012), and enumeration of E. coli $\mathrm{O} 157: \mathrm{H}^{(11)}$ and lactic acid bacteria (LAB) by International Organization for Standardization (ISO) 7889:2003 methods ${ }^{(12)}$. The milk was inoculated with an enough amount of E. coli O157:H7 to yield a final concentration of 4 log CFU.mL ${ }^{-1}$ in milk samples, according to the Mac Farland scale. This procedure was made before lactose hydrolysis and yogurt production. Inoculations were done into preheated milk at $40{ }^{\circ} \mathrm{C}$. Control yogurt was also kept at this temperature to avoid variations when the starter culture was added.

Two different types of yogurt were prepared, each one of them with two treatments: traditional (TY); traditional with E. coli O157:H7 (TEY); low lactose (LLY); and low lactose with E. coli O157:H7 (LLEY). All types of yogurt were produced using pre-heated whole milk at $40{ }^{\circ} \mathrm{C}$. Traditional yogurt was prepared with milk (control and inoculated) and starter culture. The low lactose yogurt was prepared from whole milk (control and inoculated) pretreated with $\beta$ galactosidase $(450 \mathrm{~mL} / 1000 \mathrm{~L}$ of milk) (Maxilact LX 5000, DSM Food Specialties, Delft, Netherlands) for $1 \mathrm{~h}$ at $40{ }^{\circ} \mathrm{C}$ and inoculated with starter culture. All yogurt was incubated at $42{ }^{\circ} \mathrm{C}$ $\pm 1^{\circ} \mathrm{C}$ until reach the final $\mathrm{pH}$ of $4.5-4.6$ and then stored at $4{ }^{\circ} \mathrm{C}$. Samples were taken for $\mathrm{pH}$ determination at each hour of fermentation.

Bacterial count was performed with dilution of $25 \mathrm{~g}$ of each sample into $225 \mathrm{~mL}$ of $0.1 \%$ peptone saline water and homogenization in Stomacher ${ }^{\circledR}$ blender for $1 \mathrm{~min}$. After this step, $1 \mathrm{~mL}$ of each initial dilution was transferred into tubes with $9 \mathrm{~mL}$ of $0.1 \%$ peptone saline water and serially dilutions were made until $10^{-10}$. E. coli O157:H7 was determined by pour plate technique, plating 1 
mL of appropriate dilutions before Fluorocult Escherichia coli O157:H7Agar (Merck, Darmstadt, Germany) $^{(11)}$. Random isolates were confirmed by serology with E. coli O157 antiserum (Probac, São Paulo, Brazil).

For enumeration of lactic acid bacteria (LAB) the ISO methods were used and $1 \mathrm{~mL}$ aliquots of determined dilutions were added into a Petri dish to perform the counts by pour plates technique. M17 Agar (Difco Laboratories, Michigan, USA) was poured over the samples for the isolation of $S$. thermophilus and incubated at $37^{\circ} \mathrm{C}$ for $48 \mathrm{~h}$. For L. bulgaricus count, acidified (5.4) Man-RogosaSharpe (MRS) Agar (Difco Laboratories, Michigan, USA) was poured and the plates were incubated anaerobically in a GasPak ${ }^{\mathrm{TM}}$ container (Becton, Dickinson and Company, New Jersey, USA) at $37{ }^{\circ} \mathrm{C}$ for $72 \mathrm{~h}^{(12)}$. The enumeration of E. coli O157:H7 was determined at 0 , 6, and 12 hours after inoculation and enumeration of LAB was performed 12 hours after the end of fermentation.

The $\mathrm{pH}$ values of the samples were measured by immersing the electrode of a digital pHmeter (PG 1800, Cap Lab, São Paulo, Brazil) directly in the sample ${ }^{(13)}$.

Data from physicochemical analysis and microbial counts were subjected to one-way analysis of variance (ANOVA), testing the differences between the different types of yogurt at each sampling time. All ANOVA were subjected to Tukey's test at $\mathrm{P}<0.05$. Statistical analysis were performed using XLSTAT version 2013.2.03 (Addinsoft, Paris, France)

\section{Results and Discussion}

The $\mathrm{pH}$ of all groups dropped during the fermentation process, as expected due to LAB metabolism and acid production. The $\mathrm{pH}$ values of the yogurt inoculated with E. coli O157:H7 after 6 h of fermentation were significantly higher $(\mathrm{P}<0.05)$ than the values of non-inoculated yogurt. Also, there was no difference between control treatments after $6 \mathrm{~h}$ of fermentation as illustrated in Tab. 1 . In accordance with our results, Rodriguez et al. ${ }^{(14)}$, Vénica et al. ${ }^{(15)}$ and Wolf et al. ${ }^{(16)}$ showed that the lactose hydrolysis did not affect the acidification process, and no differences in $\mathrm{pH}$ values between yogurt prepared from milk with different lactose contents and control yogurt were found. In inoculated groups, the $\mathrm{pH}$ difference might be related to the competition between LAB and $E$. coli O157:H7 for carbon sources.

Table 1. $\mathrm{pH}$ values during yogurts fermentation

\begin{tabular}{ccccccc}
\hline \multirow{2}{*}{ Treatment } & \multicolumn{5}{c}{ Fermentation time (hours) } \\
\cline { 2 - 7 } & $\mathbf{1}$ & $\mathbf{2}$ & $\mathbf{3}$ & $\mathbf{4}$ & $\mathbf{5}$ & $\mathbf{6}$ \\
\hline TY & $6.64^{\mathrm{Aa}}$ & $6.24^{\mathrm{Bb}}$ & $5.13^{\mathrm{Dc}}$ & $4.79 \mathrm{Cd}$ & $4.63 \mathrm{Ce}$ & $4.53^{\mathrm{Cf}}$ \\
LLY & $6.65^{\mathrm{Aa}}$ & $6.45^{\mathrm{Ab}}$ & $5.39^{\mathrm{Ac}}$ & $4.9 \mathrm{Ad}$ & $4.75^{\mathrm{Ae}}$ & $4.54^{\mathrm{Cf}}$ \\
TEY & $6.46^{\mathrm{Ba}}$ & $6.18^{\mathrm{Cb}}$ & $5.21^{\mathrm{Cc}}$ & $4.81^{\mathrm{BCd}}$ & $4.68 \mathrm{Be}$ & $4.62^{\mathrm{Bf}}$ \\
LLEY & $6.41^{\mathrm{Ca}}$ & $6.04^{\mathrm{Db}}$ & $5.29^{\mathrm{Bc}}$ & $4.87^{\mathrm{ABd}}$ & $4.68 \mathrm{Be}$ & $4.67 \mathrm{Ae}$ \\
2-d Letters indicate significant differences in the treatment, P $<0.05$. \\
A-D Letters indicate significant differences among the different treatments, P<0.05. \\
TY: Traditional yogurt, LLY: Low lactose yogurt, TEY: Traditional inoculate yogurt, LLEY: \\
Low lactose inoculated yogurt.
\end{tabular}


During fermentation, at the third hour the yogurt inoculated with E. coli O157:H7 began to show a formation of small bubbles of gas due to E. coli metabolism, forming $\mathrm{CO}_{2}$ gas (Fig. 1A). Over the hours, these bubbles became increasingly abundant and an intense syneresis was observed (Fig. 1B). The final products after 6 hours of fermentation were visually changed, and it was not possible to observe homogeneous and firm coagulum as observed in non-inoculated yogurts.

Xu et al. ${ }^{(17)}$ observed that different strains of E. coli O157:H7 are capable to rapidly ferment lactose and glucose with gas production. In this study, the results showed that this fermentation occurred and the rapid growth of E. coli O157:H7 was facilitated by incubation at $40{ }^{\circ} \mathrm{C}$ of all types of yogurt during one hour for lactose hydrolysis. Another factor that influenced $E$ coli growth was the absence of microbial competition and acidification from the starter cultures during the early times of hydrolysis.

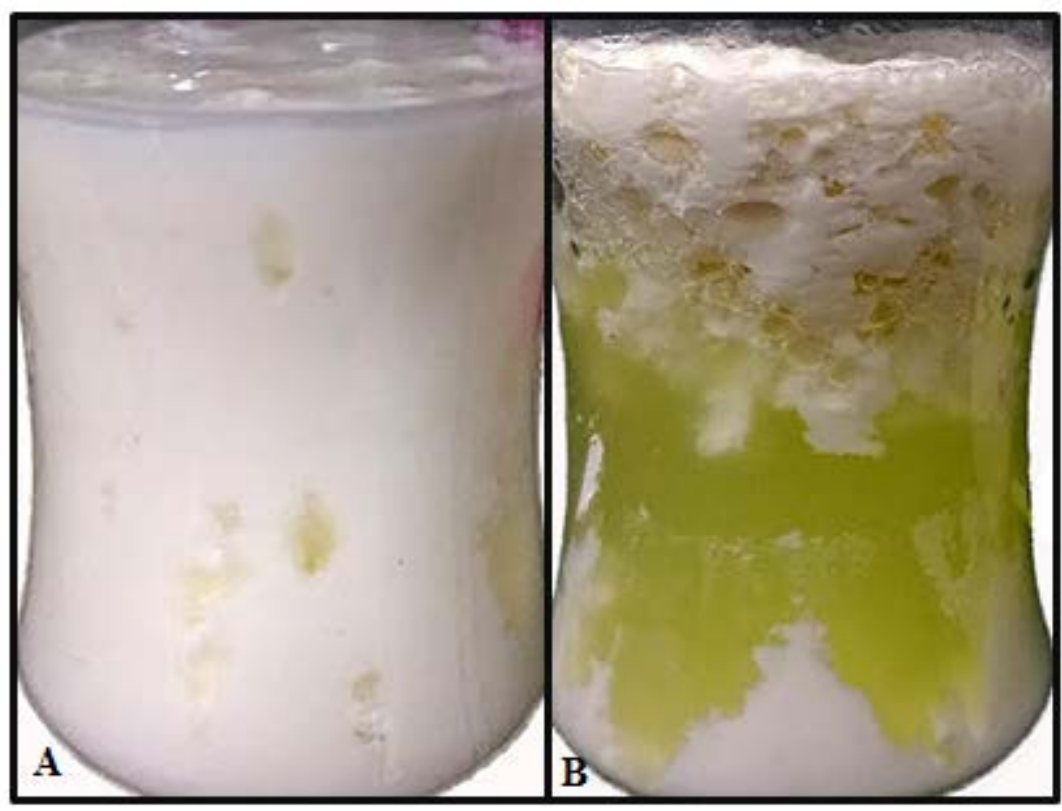

Figure 1. Initial gas formation of inoculated yogurt (A) and final product after $6 \mathrm{~h}$ of fermentation (B).

Some researchers have studied the survival of E. coli O157:H7 in food systems, especially yogurt, and they have related the survival of the cells during fermentation process ${ }^{(5,18)}$. Our results suggested E. coli O157:H7 was able to grow despite the acidic environment developed and the bacterial competition.

E. coli O157:H7 was not found in non-inoculated yogurt (control). Counts right after inoculation and after fermentation increased from $4.34 \log$ CFU mL-1 in both groups to $6.13 \log$ CFU mL ${ }^{-1}$ and $6.16 \log$ CFU mL ${ }^{-1}$ in TEY and LLEY, respectively. After $12 \mathrm{~h}$ of cooling at $4{ }^{\circ} \mathrm{C}$, counts increased

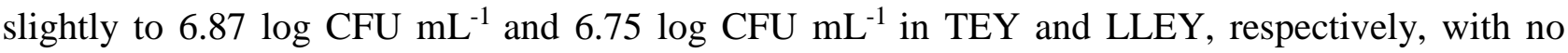
significantly difference between then.

Our results are in accordance with those observed by Kasımoglu and Akgün ${ }^{(19)}$ and Bachrouri et al. ${ }^{(5)}$, who reported counts of E. coli O157:H7 increased about $1 \log$ CFU mL ${ }^{-1}$ from initial inoculum during fermentation process. In the same context, Osaili et al. ${ }^{(18)}$ reported a large increase of E. coli $\mathrm{O} 157: \mathrm{H} 7$ count of $3.05 \log \mathrm{CFU} \mathrm{mL} \mathrm{m}^{-1}$ during the fermentation process. After the 
fermentation process, we found similar results as Ogwaro et al. ${ }^{(20)}$ and Cirone et al. ${ }^{(21)}$, who reported an increase of E. coli $\mathrm{O} 157: \mathrm{H7}$ counts from $5 \mathrm{CFU} \mathrm{mL}^{-1}$ to $8-9 \log \mathrm{CFU} \mathrm{mL} \mathrm{m}^{-1}$ and $5.3 \mathrm{CFU} \mathrm{mL}^{-1}$ to $6.4 \log$ CFU mL $\mathrm{m}^{-1}$ after $24 \mathrm{~h}$ of fermentation, respectively.

The results of the present study suggested E. coli $0157: \mathrm{H} 7$ was able to adapt to the acid environment and grow even after cooling and storage at low temperature. Moreover, $E$ coli was able to use different carbon sources for growth because no significant difference in its growth was observed in both groups with different lactose content. These findings are supported by results reported by $\mathrm{Xu}$ et al. ${ }^{(17)}$, Adler and $\mathrm{Kaiser}^{(22)}$, and Ozbudak et al. ${ }^{(23)}$, that $E$ coli is able to use different carbon sources like glucose, lactose and galactose.

The means of S. thermophilus and L. bulgaricus counts after $12 \mathrm{~h}$ of cooling are shown in Tab. 2 . Our results suggested the reduction of lactose content already affects significantly $(\mathrm{P}<0.05)$ the LAB counts and the presence of $E$ coli O157:H7 also affects L. bulgaricus counts, lowering even more when associated with lactose reduction.

Table 2. Counts of S. thermophilus and L. bulgaricus in yogurt after $12 \mathrm{~h}$ of cooling and storage at $4{ }^{\circ} \mathrm{C}$

\begin{tabular}{ccc}
\hline \multirow{2}{*}{ Treatment } & \multicolumn{2}{c}{ Counts (log CFU.mL S. $^{-1}$ ) } \\
& S. thermophilus & L. bulgaricus \\
\hline TY & $9.83^{\mathrm{A}}$ & $10.35^{\mathrm{A}}$ \\
LLY & $9.72^{\mathrm{B}}$ & $9.84^{\mathrm{B}}$ \\
TEY & $8.31^{\mathrm{C}}$ & $8.36^{\mathrm{C}}$ \\
LLEY & $6.85^{\mathrm{D}}$ & $5.85^{\mathrm{D}}$ \\
\hline A-D Letters indicate significant differences among the different treatments, P<0.05. \\
TY: Traditional yogurt, LLY: Low lactose yogurt, TEY: Traditional inoculated yogurt, LLEY: Low \\
lactose inoculated yogurt.
\end{tabular}

Researchers have demonstrated that $S$. thermophilus and L. bulgaricus show a mutually favorable interaction. L. bulgaricus produces amino acids and small peptides that stimulate $S$. thermophilus growth by acting as an amino acid source ${ }^{(24,25)}$, and $S$. thermophilus produces carbon dioxide and formic acid that stimulate L. bulgaricus ${ }^{(26)}$.

Our results showed the highest LAB counts in non-inoculated (control) yogurts confirming the symbiosis; however, we observed a significantly decrease $(\mathrm{P}<0.05)$ in counts in low lactose yogurts. Some researchers have reported that $L$. bulgaricus shows a preference of lactose over glucose and that $S$. thermophilus shows competitive and growth advantage over . bulgaricus $^{(27,28)}$. The smaller counts observed in the groups with lactose reduction in comparison with traditional yogurts could also be explained by a partial inhibition of lacSZ operon in LAB, which encodes a permease that transports lactose into cells and $\beta$-galactosidase due to the absence of lactose and presence of free glucose from hydrolyzed milk as shown by Lapierre et al. ${ }^{(29)}$.

It has been reported that most strains of $S$. thermophilus are phenotypically galactose-negative and do not contain the necessary genes for galactose metabolism. They are able to metabolize only glucose portion of lactose and expel galactose into the medium ${ }^{(30,31)}$, hindering its growth in medium with reduced lactose content. As most strains of $S$. thermophilus are unable to ferment galactose, they did not grow and did not produce acids that stimulate L. bulgaricus growth either. Our results corroborate these findings because in both low lactose treatments we observed reduced 
counts of $L$. bulgaricus in comparison with $S$. thermophilus, which seemed to be better adapted to a low lactose content and able to use glucose as a carbon source.

In both inoculated treatments, significantly lower LAB counts were observed, especially in reduced lactose samples. These results may be related to both lactose hydrolysis, that restricts the growth of $\mathrm{LAB}$, and the competition with $E$ coli for residual lactose and glucose that seemed to be more rapidly used by E. coli O157:H7.

\section{Conclusion}

We concluded that E. coli O157:H7 was able to survive and grow during fermentation of traditional and low lactose yogurt, affecting the manufacture technology and reducing yogurt LAB counts. Moreover, milk contamination by E. coli before addition of LAB starters reduced the growth of $L$. bulgaricus and $S$. thermophilus, especially when associated with reduction of lactose content.

\section{References}

1. Willey J, Sherwood L, Woolverton C. Microbiology. $7^{\text {th }}$ Edition. McGraw-Hill, New York, USA. 2008. 1088p. English.

2. Riley LW, Remis RS, Helgerson SD, McGee JB, Wells JG, Davis BR, Hebert RJ, Olcott ES, Johnson LM, Hargrett NT, Blake PA, Cohen ML. Hemorrhagic colitis associated with a rare Escherichia coli serotype. The New England Journal of Medicine. 1983; 308:681-685.

3. Centers for Disease Control and Prevention. Multistate Outbreak of Shiga toxin-producing Escherichia coli O157:H7 Infections Linked to Ground Beef. [Internet] USA: Centers for Disease Control and Prevention; 2014 Jun 20 [cited 2015 Jul 20]. Available from: http://www.cdc.gov/ecoli/2014/O157H7-0514/index.html. English

4. Morgan D, Newman CP, Hutchinson DN, Walker AM, Rowe B, Majid F. Verotoxin producing Escherichia coliO157 infections associated with the consumption of yoghurt. Epidemiology and Infection. 1993; 111:181-187.

5. Bachrouri M, Quinto EJ, Mora MT. Survival of E. coli O157: H7 during storage of yogurt at different temperature. Journal of Food Science. 2002;67:1899-1903.

6. Evrendilek GA. Survival of Escherichia coli O157:H7 in yogurt drink, plain yogurt and salted (tuzlu) yogurt: Effects of storage time, temperature, background flora and product characteristics. International Journal of Dairy Technology. 2007;60 (2):118-122.

7. Meng J, Doyle MP, Zhao T, Zhao S. Enterohemorrhagic Escherichia coli. In: Doyle, MP, Buchanan, RL, editors. Food Microbiology: Fundamentals and Frontier. ASM Press, Washington, USA, 2007; p.249-269. English.

8. Mattar R, Mazo DFC, Carrilho FJ. Lactose intolerance: diagnosis, genetic, and clinical factors. Clinical and Experimental Gastroenterology. 2012;5:113-121.

9. Schaafsma, G. Lactose and lactose derivatives as bioactive ingredients in human nutrition. International Dairy Journal. 2008;18(5):458-465. 
10. London LEE, Chaurin V, Auty MAE, Fenelon MA, Fitzgerald GF, Ross RP, Stanton C.. Use of Lactobacillus mucosae DPC 6426, an exopolysaccharide producing strain, positively influences the technofunctional properties of yoghurt. International Dairy Journal.2015;40:33-38.

11. Merck. Microbiology Manual. MerckKGaA, Darmstadt, Germany, 2007,p.287-288.

12. International Organization for Standardization. ISO7889:2003 - Yogurt -- Enumeration of characteristic microorganisms -- Colony-count technique at $37^{\circ} \mathrm{C}$. 2003; 11p.

13. Association of Official Analytical Chemists (AOAC). Dairy Products. In :Latimer GW Jr. editor. Official methods of analysis of Association of Official Analytical Chemists. AOAC Inc, Arlington, USA, 2012 p.1100.

14. Rodriguez VA, Cravero BF, Alonso A. Process of elaboration of delactosed yogurt from goat's milk. Food Science and Technology (Campinas). 2008;28:109-115. Spanish

15. Vénica C, Bergamini C, Zalazar C, Perotti C. Effect of lactose hydrolysis during manufacture and storage of drinkable yogurt. Journal of Food \& Nutritional Disorders. 2013;2: 1-7.

16. Wolf IV, Vénica CI, Perotti MC. Effect of reduction of lactose in yogurts by addition of $\beta$-galactosidase enzyme on volatile compound profile and quality parameters. International Journal of Food Science and Technology. 2015;50(5):1076-1082.

17. Xu JG, Quan TS, Xiao DL, Fan TR, Li LM, Wang CA, Li W, Liu HM. Isolation and characterization of Escherichia coli O157:H7 strains in China. Current Microbiology. 1990; 20: 299-303.

18. Osaili TM, Taani M, Al-Nabulsi AA, Attlee A, Odeh RA, Holley RA, Obaid RS. Survival of Escherichia coliO157:H7 during the Manufacture and Storage of Fruit Yogurt. Journal of Food Safety. 2013;33(3):1745-4565.

19. Kasımoğlu A, Akgün S. Survival of Escherichia coli O157: H7 in the processing and post-processing stages of acidophilus yogurt. International Journal of Food Science and Technology. 2004;39(5):563-568.

20. Ogwaro BA, Gibson H, Whitehead M, Hill DJ. Survival of E. coli O157: H7 in traditional African yoghurt fermentation. International Journal of Food Microbiology. 2002;79:105-112.

21. Cirone K, Huberman Y, Morsella C, Méndez L, Jorge M, Paolicchi F. Growth of Mycobacterium avium subsp. paratuberculosis, Escherichia coli, and Salmonella Enteritidis during Preparation and Storage of Yogurt. ISRN Microbiology.2013, 7p.

22. Adler J.; Kaiser AD. Mapping of the galactose genes of Escherichia coli by transduction with phage P1. Virology. 1963; 19(2):117-126.

23. Ozbudak EM, Thattai M, Lim HN, Shraiman BI, Van Oudenaarden A. Multistability in the lactose utilization network of Escherichia coli. Nature. 2004; 427(6976):737-740.

24. Accolas JP, Veaux M, Auclair J. Etude des interactions entre diverses bactéries lactiques thermophiles et mésophiles, en relation avec la fabrication de fromages à pate cuite. Lait. 1971;51:249-272.

25. Radke-Mitchell L, Sandine, WE. Associative growth and differential enumeration of Streptococcus thermophilus and Lactobacillus bulgaricus: a review. Journal of Food Protection. 1984;47: 245-248.

26. Suzuki I, Kato S, Kitada T, Yano N, Morichi T. Growth of Lactobacillus bulgaricus in milk. 1. Cell elongation and the role of formic acid in boiled milk. Journal of Dairy Science. 1986; 69:311-320. 
27. Ben-Yahia L, Mayeur C, Rul F, Thomas M. Growth advantage of Streptococcus thermophilus over Lactobacillus bulgaricus in vitro and in the gastrointestinal tract of gnotobiotic rats. Beneficial Microbes. 2012;3(3):211-9.

28. Tabasco R, Palencia PF, Fontecha J, Peláez C, Requena T. Competition mechanisms of lactic acid bacteria and bifidobacteria: Fermentative metabolism and colonization. LWT - Food Science and Technology. 2014;55(2):680-684.

29. Lapierre L, Mollet B, Germond JE. Regulation and adaptive evolution of lactose operon expression in Lactobacillus delbrueckii. Journal of. Bacteriology. 2002;184:928-935.

30. Mora D, Fortina MG, Parini C, Ricci G, Gatti M, Giraffa G, Manachini PL. Genetic diversity and technological properties of Streptococcus thermophilus strains isolated from dairy products. Journal of Applied Microbiology. 2002;93(2):278-287.

31. De Vin F, Rådström P, Herman L, De Vuyst L. Molecular and biochemical analysis of the galactose phenotype of dairy Streptococcus thermophilus strains reveals four different fermentation profiles. Applied and Environmental Microbiology. 2005; 7:3659-3667. 